\title{
Regulation of TH1- and TH2-type cytokine expression and action in atopic asthmatic sensitized airway smooth muscle
}

\author{
Hakon Hakonarson, Neil Maskeri, Carrie Carter, and Michael M. Grunstein
}

Division of Pulmonary Medicine, Joseph Stokes, Jr., Research Institute, The Children's Hospital of Philadelphia, University of Pennsylvania School of Medicine, Philadelphia, Pennsylvania 19104, USA

Address correspondence to: Michael M. Grunstein, Division of Pulmonary Medicine, The Children's Hospital of Philadelphia, University of Pennsylvania School of Medicine, 34th Street and Civic Center Boulevard, Philadelphia, Pennsylvania 19104, USA. Phone: (215) 590-3497; Fax: (215) 590-1397; E-mail: grunstein@email.chop.edu

Received for publication November 16, 1998, and accepted in revised form February 16, 1999.

\begin{abstract}
$\mathrm{CD}^{+} \mathrm{T}$ helper (TH)1- and TH2-type cytokines reportedly play an important role in the pathobiology of asthma. Recent evidence suggests that proasthmatic changes in airway smooth muscle (ASM) responsiveness may be induced by the autocrine release of certain proinflammatory cytokines by the ASM itself. We examined whether TH1- and TH2-type cytokines are expressed by atopic asthmatic sensitized ASM and serve to autologously regulate the proasthmatic phenotype in the sensitized ASM. Expression of these cytokines and their receptors was examined in isolated rabbit and human ASM tissues and cultured cells passively sensitized with sera from atopic asthmatic patients or control subjects. Relative to controls, atopic sensitized ASM cells exhibited an early increased mRNA expression of the TH2-type cytokines, interleukin-5 (IL-5) and granulocyte-macrophage colony-stimulating factor (GM-CSF), and their receptors. This was later followed by enhanced mRNA expression of the TH1-type cytokines, IL-2, IL-12, and interferon- $\gamma($ IFN- $\gamma)$, as well as their respective receptors. In experiments on isolated ASM tissue segments (a) exogenous administration of IL- 2 and IFN- $\gamma$ to atopic asthmatic serum-sensitized ASM ablated both their enhanced constrictor responsiveness to acetylcholine (ACh) and their attenuated relaxation responsiveness to $\beta$-adrenoceptor stimulation with isoproterenol, and (b) administration of IL-5 and GM-CSF to naive ASM induced significant increases in their contractility to ACh and impaired their relaxant responsiveness to isoproterenol. Collectively, these observations provide new evidence demonstrating that human ASM endogenously expresses both TH1- and TH2-type cytokines and their receptors, that these molecules are sequentially upregulated in the atopic asthmatic sensitized state, and that they act to downregulate and upregulate proasthmatic perturbations in ASM responsiveness, respectively.
\end{abstract}

J. Clin. Invest. 103:1077-1087 (1999).

\section{Introduction}

Exaggerated agonist-mediated bronchoconstriction, attenuated $\beta$-adrenoceptor-mediated airway relaxation, and airway inflammation are all characteristic features of bronchial asthma (1-4). Although the mechanism underlying these inflammation-associated changes in airway responsiveness remains largely unknown, substantial evidence in recent years supports a key role for $\mathrm{CD}^{+} / \mathrm{T}$ helper $(\mathrm{TH}) 2$ cell-derived cytokines in the pathogenesis of the pulmonary inflammatory response in asthma (5-9). Certain TH2-type cytokines, notably interleukin (IL)-4 and IL-5, are known to orchestrate various humoral and cellular immune responses, including IgE synthesis, eosinophil recruitment, and upregulated eosinophil function, that are characteristic of the inflammatory state in asthmatic airways (10-12). Moreover, there is also evidence suggesting that the TH1-type cytokines, notably interferon- $\gamma$ (IFN- $\gamma$ ), may play a protective role in countering the IgE-dependent expression of allergic responses and atopic asthma (13-18). Thus, the contemporary viewpoint is that the proasthmatic state reflects an imbalance between TH1- and TH2-type cytokine production and action, wherein an induced upregulated TH2 cytokine response, together with a rel- atively downregulated TH1 cytokine response, underlies the cellular and humoral airway inflammatory diathesis in asthma. Accordingly, it is believed that the stimulated release and action of TH 2 cytokines are responsible for orchestrating the influx of inflammatory cells into the airways and that the resultant release of various proinflammatory mediators by these cells renders the airway smooth muscle (ASM) hyperractive (5-12).

In support of the above concept, studies in children and adults $(5,19-21)$ have demonstrated that, relative to nonallergic/nonasthmatic subjects, both serum and bronchoalveolar lavage (BAL) fluid samples isolated from atopic asthmatic patients reveal significantly increased levels of IL-4 and IL-5, in association with decreased levels of IFN- $\gamma(5,19-21)$. Moreover, it has been reported that mononuclear cells isolated from serum or BAL fluid samples from atopic asthmatic patients also demonstrate a similar altered TH1- and TH2-type cytokine profile when the cells are stimulated with antigen (i.e., favoring the TH2-type cytokine response). Finally, in extended support of this concept, treatment of asthmatic patients or allergen-sensitized animals with corticosteroids has been found to reduce both airway constrictor hyperresponsiveness and BAL 

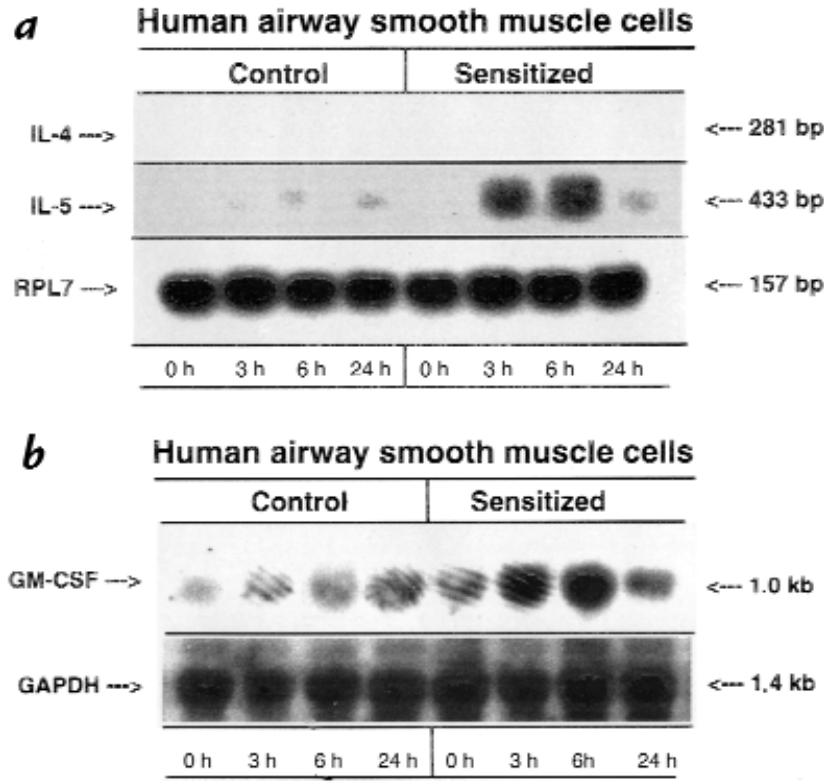

Figure 1

Comparison of expression of interleukin-4 (IL-4), interleukin-5 (IL-5), and granulocyte-macrophage colony-stimulating factor (GM-CSF) mRNAs using RT-PCR and Southern blot analysis $(\boldsymbol{a})$ and Northern blot analysis (b), respectively, in human ASM cells after 0-, 3-, 6-, and 24-h treatment with control serum vs. atopic asthmatic-sensitizing serum. Expression of ribosomal protein L7 (RPL7) (a) and glyceraldehyde phosphate dehydrogenase $(G A P D H)(b)$ mRNAs, respectively, were used to control for gel loading. The blots were probed with human specific IL-4, IL-5, GM-CSF, RPL7, and GAPDH- ${ }^{32}$ P-labeled cDNA probes (see Methods). In contrast to undetectable expression of IL-4, human ASM cells expressed mRNAs for the TH2-type cytokines, IL-5, (a) and GM-CSF (b). Additionally, relative to control serum-treated cells, the mRNA signals of IL-5 and GM-CSF were markedly increased in the atopic asthmatic serum-sensitized cells at 3 and $6 \mathrm{~h}$, whereas expression of the constitutively expressed RPL7 and GAPDH genes was unaltered. Accordingly, corrected for the constitutively expressed $m R N A s$ for RPL7 and GAPDH, relative to their respective controls, the corresponding mRNA signals for IL-5 and GM-CSF were increased at $6 \mathrm{~h}$ by approximately eightfold and fivefold, respectively. ASM, airway smooth muscle; $R T$, reverse transcriptase; $T H, T$ helper.

fluid levels of IL-4 and IL-5, as well as the percentage of cells expressing these cytokines, whereas IFN- $\gamma$ levels and cells expressing IFN- $\gamma$ in the lung are increased (22-24).

Although this evidence implies an important role for $\mathrm{CD}^{+} \mathrm{TH}$ cells in the pathobiology of atopic asthma, we have recently demonstrated (25-27)that the ASM itself can be induced to express specific cytokines, notably IL$1 \beta$, in the atopic asthmatic sensitized state and, thereby, the ASM acts in an autocrine manner to manifest endogenously its proasthmatic phenotypic responsiveness. In view of the latter, together with the aforementioned implied role of an altered TH1/TH2 cytokine profile in allergic asthma, the present study examined whether isolated rabbit and human ASM (HASM) tissue and cultured ASM cells also express TH1- and TH2-type cytokines and their receptors, whether the expression of these molecules is perturbed in the atopic asthmatic sensitized state, and whether the latter perturbation is associated with proasthmatic changes in agonist-mediated ASM constrictor and relaxant responsiveness. The results provide new evidence demonstrating that HASM tissue and cultured cells express mRNAs and proteins for both TH1- and TH2-type cytokines and their receptors, and that the expression of these cytokine and receptor molecules is altered during passive sensitization of the ASM with human atopic asthmatic serum. This evidence, together with extended findings demonstrating that TH1- and TH2-type cytokines exert opposing effects on ASM constrictor and relaxant agonist responsiveness, suggests a potentially important role for the ASM itself in autologously regulating its altered responsiveness in the atopic asthmatic state.

\section{Methods}

Animals. Thirty-two adult New Zealand white rabbits were used in this study, which was approved by the Biosafety and Animal Research Committee of the Joseph Stokes Research Institute at Children's Hospital of Philadelphia. The animals had no signs of respiratory disease for several weeks before the study.

Preparation and sensitization of rabbit ASM tissue. After anesthesia with xylazine $(10 \mathrm{mg} / \mathrm{kg})$ and ketamine $(50 \mathrm{mg} / \mathrm{kg})$, rabbits were sacrificed with an overdose of pentobarbital $(130 \mathrm{mg} / \mathrm{kg})$. The tracheae were removed via open thoracotomy, cleared of loose connective tissue, and divided into eight ring segments of 6- to 8 -mm length. Each alternative ring was then incubated for $24 \mathrm{~h}$ at room temperature in human serum containing $\operatorname{IgE}>1,000$ $\mathrm{IU} / \mathrm{ml}$ obtained from five allergic patients with moderate to severe asthma and 4-5/6+ radioallergosorbent test (RAST)-positive (specific IgE concentration of more than 17.5 Phadebas RAST units [PRU]/ml) to Dermatophagoides pteronyssimus, Dermatophagoides farinae, and ragweed, and positive skin test to these antigens. The corresponding adjacent ring segments were incubated with human serum from five nonatopic, nonasthmatic individuals with normal serum IgE levels (i.e., < $70 \mathrm{IU} / \mathrm{ml}$ ) and negative skin test reactivity, including to $D$. pteronyssimus, $D$. farinae, and ragweed (27). The sera were obtained when the subjects were clinically stable and when the atopic asthmatic individuals had not been treated with oral corticosteroids for at least four weeks before study. In parallel experiments, tracheal smooth muscle (TSM) segments were incubated in either control serum or in atopic asthmatic serum that was cotreated with IL-2, IL12 , or IFN- $\gamma$. Finally, TSM tissues were incubated in serum-free medium in the presence of IL-4, IL-5, granulocyte-macrophage colony-stimulating factor (GM-CSF), or the combination of these cytokines. Tissues incubated in medium alone served as controls. The serum was aerated with a continuous supplemental $\mathrm{O}_{2}$ mixture $\left(95 \% \mathrm{O}_{2} / 5 \% \mathrm{CO}_{2}\right)$ during the incubation phase.

Preparation of HASM tissue. ASM tissue was isolated from six nonatopic, nonasthmatic subjects who underwent lung resection for removal of bronchial carcinoma. Tumor-free ASM tissue was carefully cleaned of its epithelium and loose connective tissue and divided into several strips, and each alternate ASM strip was then passively sensitized with either human control serum or human atopic asthmatic serum for varying durations. The tissues' mRNA and protein were subsequently isolated for analyses of the expressions of TH1 and TH 2 cytokines and their respective receptors (see below).

Preparation and sensitization of human ASM cells. Cultured HASM cells obtained from Clonetics Corp. (San Diego, California, USA). The HASM cells were derived from two healthy male donors, aged 16 and 21 years. The cells were grown in smooth muscle basal medium (SmBM) supplemented with 5\% FBS, insulin $(5 \mathrm{ng} / \mathrm{ml})$, epidermal growth factor $(E G F)(10 \mathrm{ng} / \mathrm{ml}$; human recombinant), fibroblast growth factor (FGF) $(2 \mathrm{ng} / \mathrm{ml}$; human recombinant), gentamycin $(50 \mathrm{ng} / \mathrm{ml})$, and amphotericin-B $(50 \mathrm{ng} / \mathrm{ml})$. The experimental protocol involved grow- 

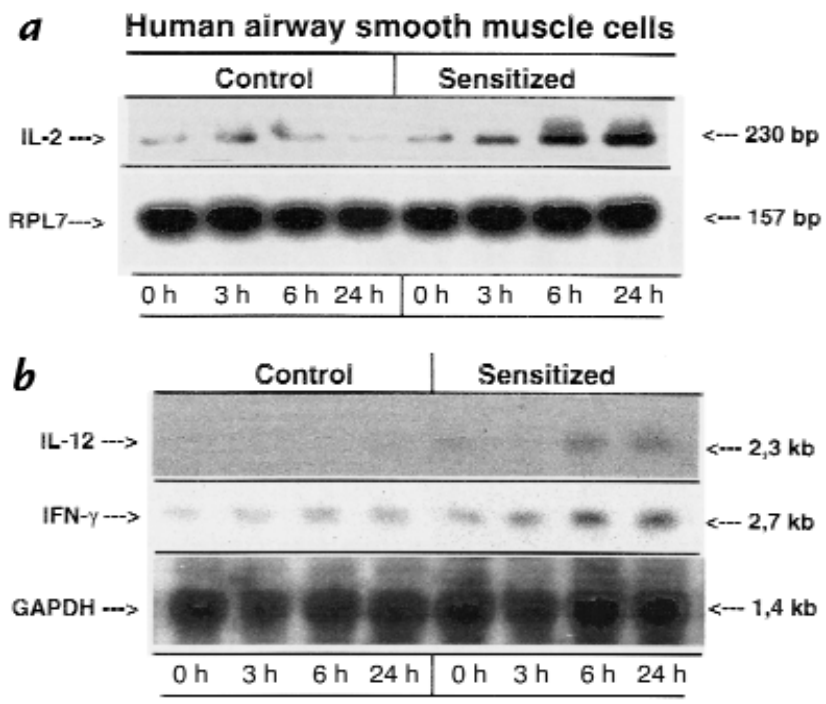

\section{Figure 2}

Comparison of expression of IL-2, IL-12, and interferon- $\gamma($ IFN- $\gamma$ ) mRNAs using RT-PCR and Southern blot analysis $(\boldsymbol{a})$ and Northern blot analysis (b), respectively, in human ASM cells after 0-, 3-, 6-, and 24-h treatment with control serum vs. atopic asthmatic-sensitizing serum. Expression of RPL7 (a) and GAPDH (b) mRNAs were used to control for gel loading. The blots were probed with human specific IL-2, IL-12, IFN- $\gamma$, RPL7, and GAPDH-32P-labeled cDNA probes (see Methods). Human ASM cells expressed mRNAs for the TH1-type cytokines, IL-2 (a) and IL-12 and IFN$\gamma(b)$. Additionally, relative to control serum-treated cells, expression of the IL-2, IL-12, and IFN- $\gamma$ mRNA signals was markedly increased in the atopic asthmatic serum-sensitized cells at 6 and $24 \mathrm{~h}$, whereas expression of the constitutively expressed RPL7 and GAPDH genes was unaltered. Accordingly, corrected to the RPL7 and GAPDH mRNAs, relative to their respective controls, the corresponding mRNA signals for IL-2, IL12 , and IFN- $\gamma$ were increased at $24 \mathrm{~h}$ by $\sim 4,3.5$, and 3 -fold, respectively.

ing the cells to confluence in this medium, as described previously (25). The cells were then starved in unsupplemented SmBM (serum-free medium [SFM]) for $24 \mathrm{~h}$, at which time the cells were treated with either human serum from nonatopic, nonasthmatic subjects (control) or serum from atopic asthmatic subjects (see earlier) in the absence and presence of cotreatment with IFN- $\gamma$. In other experiments, cells were treated with SFM alone or SFM in the presence of IL-4, IL-5, or GM-CSF. The cells were then examined for mRNA and protein expression for various cytokines and their receptors, as described next.

Determination of $m R N A$ expression of TH1 and TH2 cytokines and their receptors. Total RNA was isolated from the tissue and cell preparations using the modified guanidinium thiocyanate phenol-chloroform extraction method to include proteinase $\mathrm{K}$ (in $5 \%$ SDS) digestion of protein in the initial RNA pellet (50). The concentration of each RNA sample was determined spectrophotometrically. This procedure consistently produced yields of 15 to $25 \mu \mathrm{g}$ of intact RNA per each tissue specimen under study or T-75 flask of HASM cells. To analyze for mRNA expression of IL-4, IL-5, GM-CSF, IL-2, IL-12, IFN- $\gamma$ and their receptors, we used a reverse transcriptase (RT)-PCR protocol that included human-specific primers for these molecules, as well as for the constitutively expressed ribosomal protein (RP)L7. cDNA was synthesized from total RNA isolated from human ASM cells or ASM tissue passively sensitized with human control serum or human atopic asthmatic serum. cDNA was also prepared from activated peripheral blood mononuclear cells that served as positive controls for analysis of expression of the individual cytokines and their respective receptors. The cDNA was primed with oligo(dT) $12-18$ and extended with Superscript II reverse transcriptase (GIBCO BRL, Gaithersburg, Maryland, USA). The PCR was used to amplify the specific products from each cDNA reaction using the following primer pairs, based on the published sequences of the human IL-4, IL-5, GM-CSF, IL-2, IL-12, and IFN- $\gamma$ cytokines and their receptor genes.

\begin{tabular}{|c|c|}
\hline \multirow[t]{3}{*}{ IL-4: } & 5'-primer 5'- GTGCGATATCACCTTACAGG-3' \\
\hline & 3'-primer 5'-AACGTACTCTGGTTGGCTTA-3' \\
\hline & Product is $281 \mathrm{bp}$ \\
\hline \multirow[t]{3}{*}{ IL-5: } & 5'-primer 5'-GTATGCCATCCCCACAGAAA-3' \\
\hline & $3^{\prime}$-primer 5'-TACAGACATTCACAGCCACC-3' \\
\hline & Product is $433 \mathrm{bp}$ \\
\hline \multirow[t]{3}{*}{ GM-CSF: } & 5'-primer 5'-GTCTCCTGAACCTGAGTAGA-3' \\
\hline & 3'-primer 5'-GTTTCATGAGAGAGCAGCTC-3' \\
\hline & Product is $324 \mathrm{bp}$ \\
\hline \multirow[t]{3}{*}{ IL-5 rec.: } & 5'-primer 5'-GGCTCTTGGACTGAAGAATG-3' \\
\hline & 3'-primer 5'-GCTGCTCTCACTTGAACATC-3' \\
\hline & Product is $367 \mathrm{bp}$ \\
\hline \multirow[t]{3}{*}{ GM-CSF rec.: } & 5'-primer 5'-GACCTATCAGAAGCTGTCGT-3' \\
\hline & $3^{\prime}$-primer 5'-TTCACGGTCAAGACCTCTTC-3' \\
\hline & Product is $330 \mathrm{bp}$ \\
\hline \multirow[t]{3}{*}{ IL-2: } & 5'-primer 5'-GAATCCCAAACTCACCAGGA-3' \\
\hline & 3'-primer 5'-TTATGTTTTCTCCCACCCCC-3' \\
\hline & Product is $230 \mathrm{bp}$ \\
\hline \multirow[t]{3}{*}{ IL-12: } & 5'-primer 5'-GCAAATTCTGCCACATCTCC-3' \\
\hline & 3'-primer 5'-TATAAGTGGGTGTCTCGTCC-3' \\
\hline & Product is $310 \mathrm{bp}$ \\
\hline \multirow[t]{3}{*}{ IFN- $\gamma:$} & 5'-primer 5'-GGGTTCTCTTGGCTGTTACT-3' \\
\hline & 3'-primer 5'-ACTGAATGAGTTCCCACCAC-3 \\
\hline & Product is $322 \mathrm{bp}$ \\
\hline \multirow[t]{3}{*}{ IL-2 rec.: } & $5^{\prime}$-primer 5'-GAGGAAGGGCAAAACCACTA-3' \\
\hline & 3'-primer 5'-GAGAATCAGCAGTCAGAAGC-3' \\
\hline & Product is $224 \mathrm{bp}$ \\
\hline \multirow[t]{3}{*}{ IL-12 rec.: } & 5'-primer 5'-GATGTGACTGTGAAGCCTTC-3' \\
\hline & 3'-primer 5'-TATAAGTGGGTGTCTCGTCC-3' \\
\hline & Product is $328 \mathrm{bp}$ \\
\hline \multirow[t]{3}{*}{ IFN- $\gamma$ rec.: } & 5'-primer 5'-GTAAATGGAGACGAGCAGGA-3' \\
\hline & 3'-primer 5'-CACTTCTTACCACAGAGATC-3' \\
\hline & Product is $317 \mathrm{bp}$ \\
\hline \multirow[t]{3}{*}{ RPL7: } & 5'-primer 5'-AAGAGGCTCTCATTTTCCTGGCTG-3' \\
\hline & 3'-primer 5'-TCCGTTCCTCCCCATAATGTTCC-3' \\
\hline & Product is $157 \mathrm{bp}$ \\
\hline
\end{tabular}

The cycling profile used was as follows. Denaturation: $95^{\circ} \mathrm{C}$ for $1 \mathrm{~min}$; annealing: $50-62^{\circ} \mathrm{C}$ for $1.0-1.5 \mathrm{~min}$; and extension: $72^{\circ} \mathrm{C}$ for 1 to $2 \mathrm{~min}$, with $28-36$ cycles for the IL-4, IL-5, GMCSF, IL-2, IL-12, and IFN- $\gamma$ cytokines and cytokine receptor genes, and with 24 cycles for the RPL7 gene. The number of cycles was determined to be in the linear range of the PCR products. The PCR reactions for the human IL-4, IL-5, GMCSF, IL-2, IL-12, and IFN- $\gamma$ and RPL7 primers were performed using equivalent amounts of cDNA prepared from $2.5 \mu \mathrm{g}$ of total RNA. Equal aliquots of each PCR reaction were then run on a $1.2 \%$ agarose gel and subsequently transferred to a Zetaprobe membrane overnight in $0.4 \mathrm{~N} \mathrm{NaOH}$. After capillary transfer, the DNA was immobilized by UV cross-linking using a Stratalinker UV Crosslinker 2400 at $120,000 \mu \mathrm{J} / \mathrm{cm}^{2}$ (Stratagene, La Jolla, California, USA). Prehybridization in a hybridization oven was conducted for 2 to $3 \mathrm{~h}$ at $42^{\circ} \mathrm{C}$ in $50 \%$ formaldehyde, $7 \%$ (wt/vol) SDS, $0.25 \mathrm{M} \mathrm{NaCl}, 0.12 \mathrm{M}$ $\mathrm{Na}_{2} \mathrm{HPO}_{4}$ (pH 7.2), and $1 \mathrm{mM}$ EDTA. Hybridization was for 20 $\mathrm{h}$ at $42^{\circ} \mathrm{C}$ in the same solution. The IL-4, IL-5, GM-CSF, IL-2, IL-12, IFN- $\gamma$, and RPL7 DNA levels were then assayed by Southern blot analysis using ${ }^{32} \mathrm{P}-$ labeled probes, prepared by pooling several RT-PCR reactions for the individual cytokine/receptor and RPL7 PCR fragments and purifying 


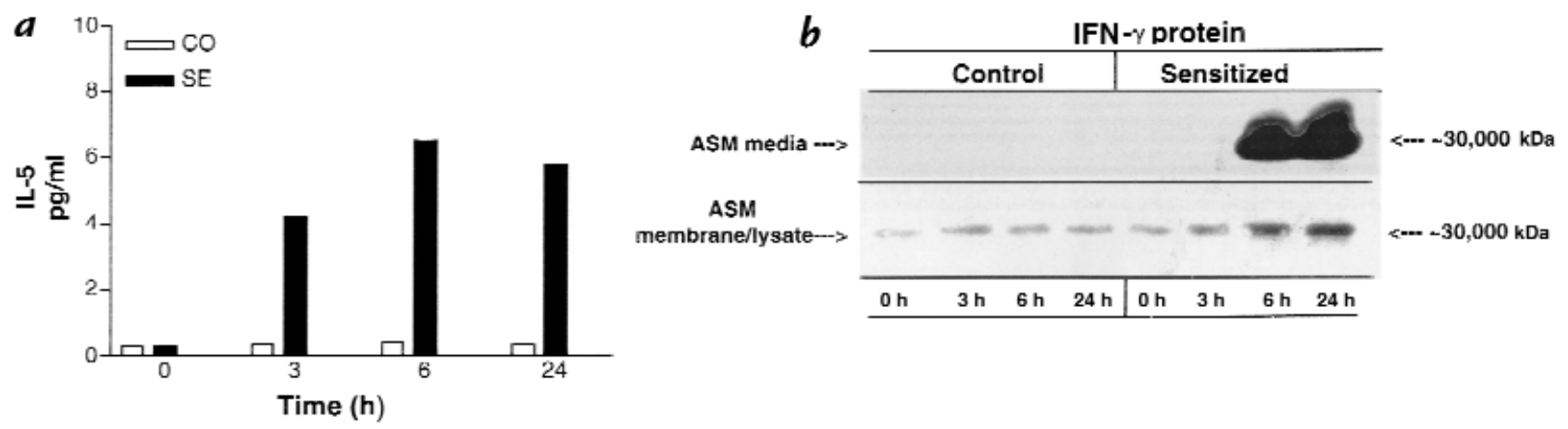

Figure 3

Comparison of human IL-5 (a) and IFN- $\gamma(\boldsymbol{b})$ protein elaboration into the culture media of human ASM cells after 0-, 3-, 6-, and 24-h exposure to human control serum (open bars) and human atopic asthmatic serum (filled bars). The IL-5 and IFN- $\gamma$ protein levels were determined by ELISA ( $a$ ) and Western blot analysis $(b)$, respectively. Human ASM cells exposed to atopic asthmatic serum released significantly increased levels of IL-5 (a) and IFN$\gamma(b)$ protein into their tissue culture media, whereas treatment with human control serum had no appreciable effect.

them from a $1.2 \%$ agarose gel using the QIAEX II agarose gel extraction kit (QIAGEN Inc., Valencia, California, USA) The individual cDNA fragments were subsequently sequenced for product confirmation. Washes were as follows: $1 \times 15 \mathrm{~min}$ in $2 \times$ SSC, $0.1 \%$ SDS and $1 \times 15 \mathrm{~min}$ in $0.1 \times$ SSC, $0.1 \%$ SDS, both at room temperature; and $2 \times 15 \mathrm{~min}$ at $50^{\circ} \mathrm{C}$ in $0.1 \times \mathrm{SSC}$, $0.1 \%$ SDS. Southern blots were quantitated by direct measurements of radioactivity in each band using a PhosphorImager (Molecular Dynamics, Sunnyvale, California, USA).

Cytoplasmic RNA $(20 \mu \mathrm{g})$ pertaining to each time point was also fractionated in $1 \%$ agarose, formaldehyde denaturing gels. After capillary transfer, cross-linking and prehybridization, the levels of mRNA were analyzed using the ${ }^{32}$ P-labeled cDNA fragments as already described here for the individual IL-4, IL-5, GM-CSF, IL-2, IL-12, and IFN- $\gamma$ cytokines and their receptor genes prepared by random priming, as well as for the constitutively expressed glyceraldehyde phosphate dehydrogenase (GAPDH) gene, as described previously in our laboratory (25). Northern blots were quantitated by direct measurement of radioactivity in each band using the PhosphorImager.

Determination of expression of TH1- and TH2-type receptor proteins. Expression of cell surface protein for the IL-4, IL-5, IL-2, IL-12, and IFN- $\gamma$ receptors was assayed by Western blot analysis of membrane protein samples isolated from cultured HASM cells and ASM tissue passively sensitized with either human control serum or human atopic asthmatic serum. The membrane protein samples were prepared from trachealis muscle that was cleaned of loose connective tissue and epithelium. The ASM was then minced and homogenized using a dounce tissue grinder in 40 volumes of $50 \mathrm{mM}$ Tris- $\mathrm{HCl}, 150 \mathrm{mM} \mathrm{NaCl}, 1 \mathrm{mM}$ EDTA (pH 7.4) containing $1 \mathrm{mM}$ PMS, $5 \mu \mathrm{g} / \mathrm{ml}$ aprotinin, and $5 \mu \mathrm{g} / \mathrm{ml}$ leupeptin. Nuclei and large particulates were removed by centrifugation at $100 \mathrm{~g}$ for $5 \mathrm{~min}$. The supernatant was then centrifuged at $100,000 \mathrm{~g}$ for $1 \mathrm{~h}$ to pellet the membrane fractions. The membrane pellet was resuspended in the same Tris-EDTA buffer, and the protein concentration was measured using the Lowry assay. Equivalent amounts $(30-50 \mu \mathrm{g})$ of membrane protein were fractionated in $9 \%$ to $11 \%$ SDS-polyacrylamide gels followed by transfer to nitrocellulose membranes. The membranes were then blotted overnight at room temperature in 25 $\mathrm{mM}$ Tris- $\mathrm{HCl}$ ( $\mathrm{pH} 7.5), 150 \mathrm{mM} \mathrm{NaCl}$, and $0.05 \%$ Tergitol NP40 containing $5 \%$ nonfat milk, as described previously in our laboratory (27). The primary mouse anti-human IL-4, IL-5, IL2 , IL-12, and IFN- $\gamma$ receptor antibodies used were diluted 1:250-1:1,000 and incubated for 1 to $2 \mathrm{~h}$ at room temperature. All primary and secondary antibody incubations and washes were conducted in $25 \mathrm{mM}$ Tris- $\mathrm{HCl}$ ( $\mathrm{pH} 7.5), 150 \mathrm{mM} \mathrm{NaCl}$, and $0.05 \% \mathrm{NP}-40$ containing $0.5 \%$ nonfat milk. The receptor protein levels were detected using enhanced chemiluminescence after a 1-h incubation with a 1:1,000 dilution of an anti-mouse horseradish peroxidase-linked secondary antibody and subsequent exposure to autoradiography film. Expression protein levels were quantitated using laser densitometry (Bio-Rad Laboratories Inc., Hercules, California, USA).

Measurements of release of IL-5 and IFN- $\gamma$ proteins. IL- 5 and IFN$\gamma$ protein levels were measured in the culture media from HASM cells at baseline and after 3-, 6-, and 24-h exposure to human control serum or human atopic asthmatic serum. The IL-5 protein levels were quantitatively assessed using enzymespecific immunoassay, as described previously (25). The latter assay was performed using a double-antibody sandwich strategy in which an acetylcholine-esterase (AChE), Fab conjugated IL-5-specific secondary antibody is targeted to a first cytokinecaptured antibody. The enzymatic activity of the AChE was measured spectrophotometrically, and, relative to a linear standard curve (range: $0-250 \mathrm{pg} / \mathrm{ml}$ ), the results were used to quantify the amount of the targeted IL- 5 present in the cell culture media at various times after serum incubation. IFN- $\gamma$ protein was examined by Western blot analysis of ASM cell culture media concentrates and membrane fraction isolates prepared from the ASM cells at the various time points. The membrane proteins were isolated as already described here. The cell culture media were separately salvaged at the various time points and centrifuged, and the resulting protein pellets were resuspended in buffer and loaded on SDS-polyacrylamide gels, as described previously by our laboratory (26). The conditions for use of the primary mouse anti-human IFN- $\gamma$ monoclonal antibody (diluted 1:500), the secondary antibody, and detection of IFN- $\gamma$ protein levels were identical to those already described here and as described previously by our laboratory (26).

Pharmacodynamic studies. After the incubation of rabbit ASM tissue preparations in control vs. atopic asthmatic serum, each airway segment was suspended longitudinally between stainless steel triangular supports in siliconized Harvard 20-ml organ baths. The lower support was secured to the base of the organ bath, and the upper support was attached via a gold chain to a Grass FT.03C force transducer (Grass Instrument Co., Quincy, Massachusetts, USA) from which isometric tension was continuously displayed on a multichannel recorder. Care was taken to place the membranous portion of the tracheal segment between the supports in order to maximize the recorded tension generated by the contracting trachealis muscle. The tissues were bathed in modified Krebs-Ringer solution containing (in mM) $125 \mathrm{NaCl}, 14 \mathrm{NaHCO}_{3}, 4 \mathrm{KCl}, 2.25$ $\mathrm{CaCl}_{2} \cdot \mathrm{H}_{2} \mathrm{O}, 1.46 \mathrm{MgSO}_{4} \cdot \mathrm{H}_{2} \mathrm{O}, 1.2 \mathrm{NaH}_{2} \mathrm{PO}_{4} \cdot \mathrm{H}_{2} \mathrm{O}$ and 11 glucose. The baths were aerated with $5 \% \mathrm{CO}_{2}$ in oxygen; a $\mathrm{pH}$ of 
7.35-7.40 was maintained, and the organ bath temperature was held at $37^{\circ} \mathrm{C}$. Passive resting tension of each TSM segment was set at 1.5-2.0 g after each tissue had been passively stretched to a tension of $8 \mathrm{~g}$ to optimize the resting length of each segment, as described previously in our laboratory (27). The tissues were allowed to equilibrate in the organ baths for $45 \mathrm{~min}$, at which time each tissue was primed with a 1 -min exposure to $10^{-4} \mathrm{M}$ acetylcholine (ACh). Cholinergic contractility was subsequently assessed in the TSM segments by cumulative administration of ACh in final bath concentrations ranging from $10^{-10}$ to $10^{-3}$ $M$. Thereafter, in separate studies, relaxation dose-response curves to isoproterenol $\left(10^{-10}-10^{-4} \mathrm{M}\right)$ were conducted in tissues half-maximally contracted with $\mathrm{ACh}$. The relaxant responses to isoproterenol were analyzed in terms of percent maximal relaxation $\left(\mathrm{R}_{\max }\right)$ from the active cholinergic contraction, and sensitivity to the relaxing agent was determined as the negative logarithm of the dose of the relaxing agent producing $50 \%$ of $\mathrm{R}_{\max }\left(\mathrm{pD}_{50}\right)$ (i.e., geometric mean $\mathrm{ED}_{50}$ value).

Statistical analysis. Statistical analysis was performed by means of the two-tailed paired Student's $t$ test. A value of $P<0.05$ was considered significant.

Reagents. The human airway tissue was provided by the Cooperative Human Tissue Network, which is funded by the National Cancer Institute. The HASM cells and SmBM were obtained from Clonetics Corp. The IL-4, IL-5, GM-CSF, IL-2, IL-12, and IFN- $\gamma$ cytokine, cytokine receptor, and RPL7 primers were purchased from Integrated DNA Technologies Inc. (Coralville, Iowa, USA). The monoclonal neutralizing antibodies to the IL4, IL-5, GM-CSF, and IL-12 cytokines and to their receptors, the anti-mouse secondary antibody, and the IL-4, IL-5, GM-CSF, IL-2, IL-12, and IFN- $\gamma$ recombinant cytokines and IL- 5 cytokine assay kit were purchased from R\&D Systems Inc. (Minneapolis, Minnesota, USA). The neutralizing antibodies to IL-2 and IFN- $\gamma$ cytokines and to their receptors were purchased from Serotec Ltd. (Oxford, United Kingdom).

\section{Results}

Altered expression of TH1 and TH2 cytokines in atopic sensitized ASM. Using Southern and Northern blot analyses, the mRNA expression and protein elaboration of various TH1- and TH2-type cytokines were compared in cultured HASM cells exposed to nonatopic/nonasthmatic (i.e., control) serum and atopic asthmatic serum. Using RT-PCR and TH1- and TH2-type cytokine-specific primers, cDNA was reverse transcribed from total isolated RNA primed with random hexamer primers, and Southern blots were then probed with human cDNA probes specific for the individual $\mathrm{TH} 1$ and $\mathrm{TH} 2$ cytokine genes (see Methods). A 157-bp ribosomal protein L7 (RPL7) probe was also used to control for gel loading, and the signals for the individual PCR products were quantitated on a PhosphorImager.

As depicted in Figure 1, under control conditions, ASM cells expressed detectable mRNA signals for the TH2-type cytokines, IL-5 and GM-CSF, which were essentially unaltered at 3, 6, and 24 hours, whereas mRNA expression of IL-4 was undetectable. In contrast, relative to the unaltered constitutively expressed RPL-7 and GAPDH signals, the corresponding intensities of the IL-5 and GMCSF mRNA signals were progressively increased at 3 and 6 hours in atopic asthmatic serum-sensitized ASM cells and decreased somewhat thereafter at 24 hours (Figure 1). Furthermore, as shown in Figure 2, mRNA expression signals were also detected in ASM cells for the TH1-type cytokines, IL-2, IL-12, and IFN- $\gamma$. However, compared
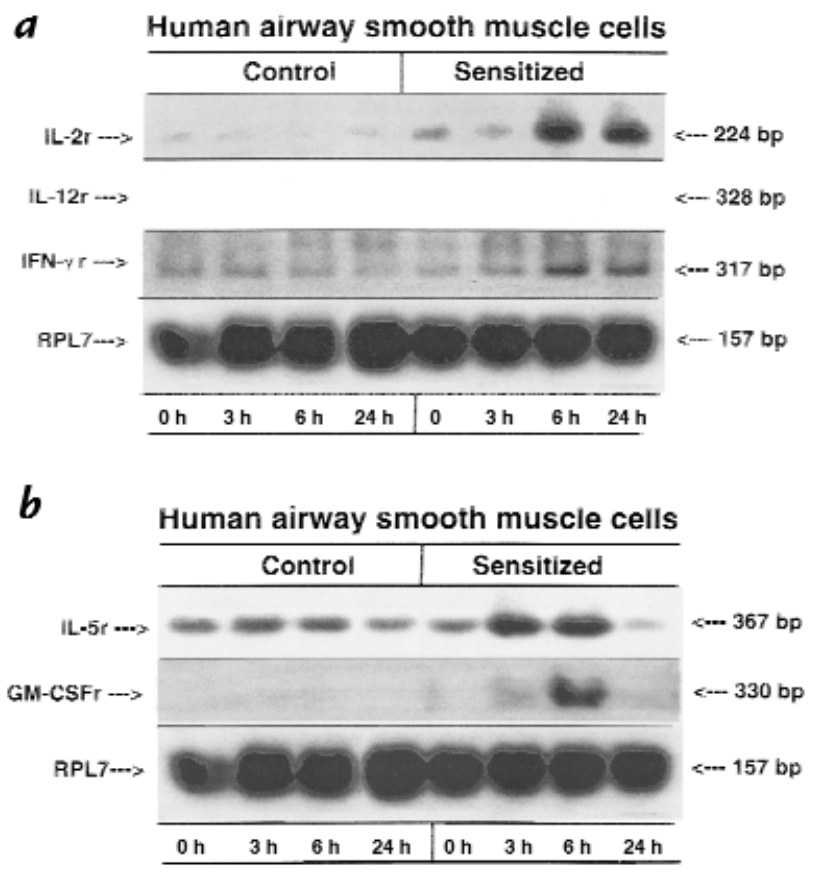

Figure 4

Comparison of mRNA expression of the TH1-type cytokine receptors for IL-2, IL-12, and IFN- $\gamma(\boldsymbol{a})$, and of the TH2-type cytokine receptors for IL-5 and GM-CSF $(\boldsymbol{b})$ using RT-PCR after exposure of human ASM cells for 0 , 3,6 , and 24 h to human control serum vs. human atopic asthmatic sensitizing serum. Expression of RPL7 was used to control for gel loading. The blots were probed with human specific IL-2, IL-12, IFN- $\gamma$, IL-5, and GMCSF ${ }^{32} \mathrm{P}$-labeled cDNA probes (see Methods). In contrast to undetectable expression of the IL-12 receptor (IL-12r) mRNA, cells expressed mRNAs of the TH1 receptors for IL-2 and IFN- $\gamma(a)$, and of the TH2 receptors for IL5 and GM-CSF $(b)$. Moreover, relative to control serum-treated cells, expression of IL-5 and GM-CSF receptor (GM-CSFr) mRNAs was notably increased at $3 \mathrm{~h}$ and thereafter in the atopic asthmatic serum-sensitized cells, whereas expression of IL- 2 and IFN- $\gamma$ receptor mRNAs was increased subsequently at $6 \mathrm{~h}$ and thereafter. Constitutively expressed RPL7 mRNA was similar under control and atopic asthmatic serum-treated conditions. Accordingly, corrected to RPL7 expression, relative to their respective controls, the IL-2 and IFN-g receptor mRNA signals were increased at 6 h by 4.5 -fold and $\sim 4$-fold, respectively.

with the earlier-described temporal pattern of induced upregulation of the TH2 cytokines in atopic asthmatic serum-sensitized ASM cells, the mRNA signals for the TH1 cytokines were notably increased only later at 6 and 24 hours in the sensitized cells.

Given these findings, we next examined whether HASM cells release TH1- and TH2-type cytokine proteins into their cell culture media, using Western blot analysis and enzyme-specific immunoassays (see Methods). There were no detectable protein levels for IFN- $\gamma$ or IL- 5 protein in the culture media of ASM cells exposed to control serum. In contrast, as depicted in Figure 3, cultured HASM cells that were exposed to atopic asthmatic serum demonstrated progressively increased elaboration of IL-5 protein into their cell culture media for up to 24 hours (Figure $3 a$ ). Similarly, relative to control serum-exposed cells, IFN- $\gamma$ protein levels were increased in both the cell media concentrates and membrane isolates of cells exposed to atopic asthmatic serum 

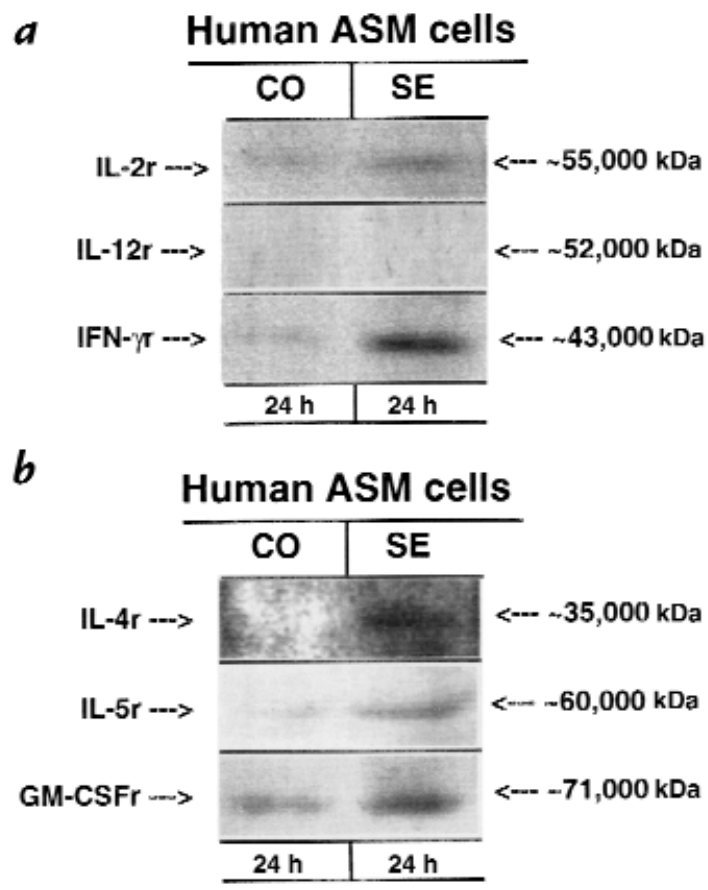

Figure 5

Representative Western blots depicting receptor protein expression of the $\mathrm{TH} 1$ cytokines, IL-2, IL-12, and IFN- $\gamma(\boldsymbol{a})$, and of the TH 2 cytokines, IL-4, $\mathrm{IL}-5$, and GM-CSF $(\boldsymbol{b})$ in membrane homogenates from human control serum-treated $(C O)$ vs. atopic asthmatic serum-sensitized $(S E)$ human ASM cells. Fifty micrograms of membrane protein was loaded in each lane. In contrast to undetectable expression of IL-12r protein, human ASM expressed cell surface receptor proteins for the TH1-type cytokines, IL-2 and IFN- $\gamma(a)$, as well as for the TH2-type cytokines, IL-4, IL-5, and GM-CSF (b). Moreover, relative to control cells, expression of both the $\mathrm{TH} 1$ - and $\mathrm{TH} 2$-type cell surface receptor proteins was significantly enhanced in the atopic asthmatic serum-sensitized cells.

(Figure 3b). There were no detectable levels of IL-4 protein in either the control or atopic-sensitized ASM cell preparations (data not shown).

Altered expression of TH1 and TH2 cytokine receptors in atopic sensitized ASM. In extended experiments, we also examined whether cultured ASM cells express mRNAs for the TH1- and TH2-type cytokine receptors and whether the expression of these receptors is altered in the atopic asthmatic sensitized state. cDNA was reverse transcribed from total isolated RNA primed with random hexamer primers, and Southern blots were probed with human cDNA probes specific for the individual TH1 and TH2 cytokine receptor genes. A RPL7 probe was also used to control for gel loading, and the signals for the individual PCR products were quantitated on a PhosphorImager (see Methods). As shown in Figure $4 a$, in control serum-exposed cells, contrasting the lack of detectable mRNA expression of the IL-12 receptor, ASM cells expressed mRNA signals for the TH1-type cytokine receptors for IL- 2 and IFN- $\gamma$. Also, the intensities of the mRNA signals for the latter cytokine receptors were markedly enhanced at 6 and 24 hours in atopic asthmatic serum-sensitized ASM cells. Comparatively, as depicted in Figure $4 b$, mRNA signals for the TH2 cytokine receptors for IL-5 and GM-CSF were also detected in control serum-exposed cells, and the intensities of these signals were notably enhanced at 3 and 6 hours in atopic asthmatic serum-sensitized ASM cells. In contrast, constitutive expression of RPL7 mRNA was similar in control and atopic asthmatic serum-treated cells. Qualitatively similar results were also obtained in comparable experiments conducted using isolated human TSM tissue, wherein, relative to control serum-exposed ASM, the signals for the TH1- and TH2type cytokine receptors in atopic-sensitized ASH demonstrated patterns of upregulation, which were similar to those obtained in cultured HASM cells exposed to atopic asthmatic serum. Comparably, RPL7 mRNA expression was unaltered in the tissue samples (data not shown).

In view of these observations, we examined in additional experiments whether ASM cells express TH1 and TH2 cytokine receptor membrane proteins on their cell surface, using Western immunoblot analysis (see Methods). As illustrated in Figure 5, in contrast to the lack of IL-12 receptor protein expression, ASM cells expressed membrane surface proteins for the TH1 cytokine receptors for IL-2 and IFN- $\gamma$ (Figure $5 a$ ), as well as for the TH2-type cytokine receptors for IL-4, IL-5, and GM-CSF (Figure 5b). Moreover, relative to the levels of expression of these proteins in control serum-treated cells, in cells exposed to human atopic asthmatic serum, cell surface protein expression of both the TH1- and TH2-type cytokine receptors were markedly upregulated at 24 hours (Figure 5, $a$ and $b$, respectively).

Modulatory actions of TH1 cytokines on ASM responsiveness in atopic sensitized $A S M$. We recently demonstrated $(25,27)$ that passive sensitization of isolated naive rabbit ASM tissue with human atopic asthmatic serum induces changes in the tissue's agonist-mediated constrictor and relaxant responsiveness that phenotypically resemble the proasthmatic state. Given this evidence, together with the findings already discussed and the previous reports suggest-

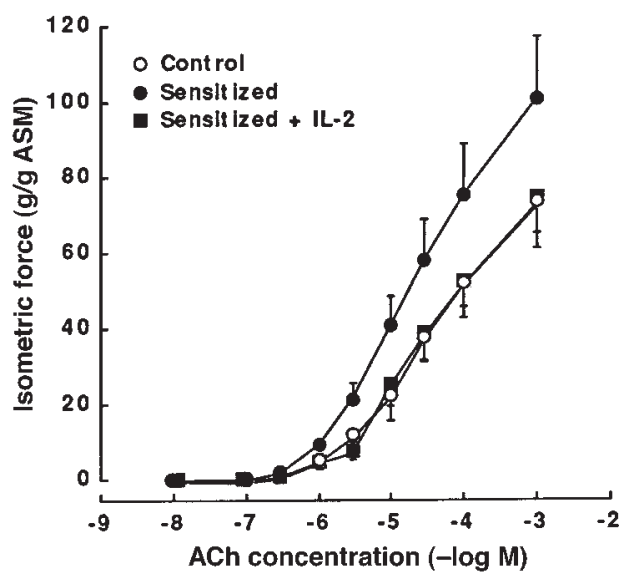

\section{Figure 6}

Comparison of contractile dose-response relationships to ACh in paired human control serum-treated (open circles) and atopic asthmatic serum-treated ASM segments in the absence (filled circles) and presence (filled squares) of maximum effective concentrations of IL-2. Relative to controls, the heightened $T_{\max }$ and $\mathrm{ED}_{50}$ responses to $\mathrm{ACh}$ in the atopic asthmatic serum-sensitized tissues were prevented by cotreatment of tissues with IL-2. Data represent mean $\pm \mathrm{SE}$ values from six paired experiments. ACh, acetylcholine. 


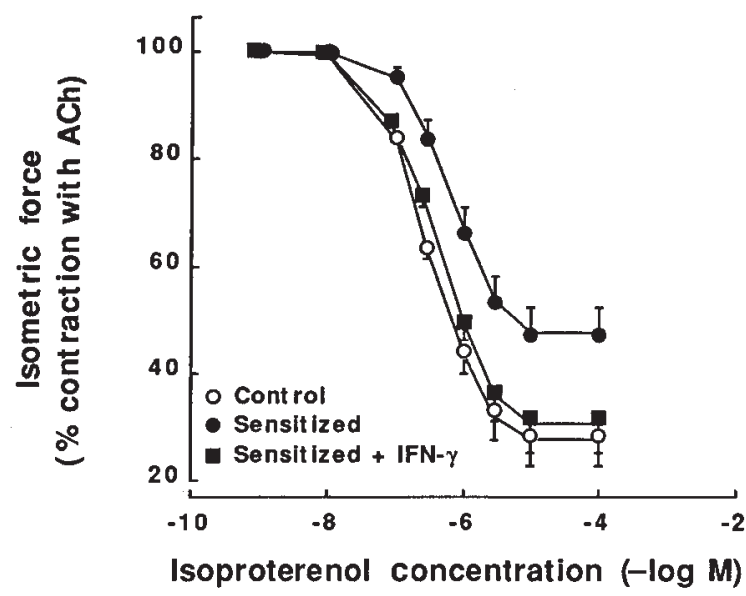

Figure 7

Comparison of relaxation dose-response relationships to isoprotereno in paired human control serum-treated (open circles) and human atopic asthmatic serum-treated rabbit ASM segments half-maximally contracted with their respective $\mathrm{ED}_{50}$ doses of $\mathrm{ACh}$ in the absence (filled circles) and presence (filled squares) of a maximum effective concentration of IFN- $\gamma$. Relative to controls, the attenuated $\mathrm{R}_{\max }$ and $\mathrm{pD}_{50}$ responses to isoproterenol in the atopic asthmatic serum-sensitized tissues were prevented by cotreatment of tissues with IFN $-\gamma$. Data represent mean \pm SE values from six paired experiments.

ing that TH1 cytokines may serve a protective role in allergic airway responses, we examined whether the sensitizing effects of atopic asthmatic serum on ASM responsiveness could be prevented by pretreating the tissues with TH1 cytokines (see Methods). Thus, constrictor and relaxation responses were separately examined in rabbit tracheal ASM segments that were incubated for 24 hours in human control serum or atopic asthmatic serum, both in the absence and presence of the TH1 cytokine, IL-2, IL-12, or IFN- $\gamma$. As shown in Figure 6, relative to tissues incubated with control serum (Figure 6, open circles), the maximal constrictor $\left(T_{\max }\right)$ responses to ACh were significantly enhanced in ASM passively sensitized with atopic asthmatic serum (Figure 6, filled circles). Accordingly, the mean $\pm \mathrm{SE} \mathrm{T}_{\max }$ values amounted to $73.16 \pm 8.47$ and $100.91 \pm$ $16.46 \mathrm{~g} / \mathrm{g}$ ASM wt in the control and sensitized tissues, respectively $(P<0.01)$. This induced augmented constrictor response to $\mathrm{ACh}$, however, was largely prevented in atopic serum-sensitized tissues that were pretreated with IL-2 (Figure 6, filled squares), wherein the mean $\pm \mathrm{SE} \mathrm{T}_{\max }$ values amounted to $74.99 \pm 13.78 \mathrm{~g} / \mathrm{g}$ ASM wt. Comparatively, pretreatment of ASM with IFN- $\gamma$ had a quantitatively lesser preventive effect, wherein the tissues' $T_{\max }$ values averaged $95.52 \pm 10.09 \mathrm{~g} / \mathrm{g}$ ASM, and pretreatment with IL-12 had no preventive effect on ACh hyperresponsiveness in the atopic sensitized state (data not shown). Moreover, contrasting the observations made in atopic asthmatic serum-sensitized ASM, pretreatment of control serum-exposed tissues with any of the above TH2 cytokines had no effect on the tissues' subsequent contractility to ACh (data not shown).

In separate studies, during comparable levels of initial sustained ACh-induced contractions in control and atopic asthmatic serum-sensitized ASM segments, averaging $\sim 45 \%$ of $\mathrm{T}_{\max }$, administration of the $\beta$-adrenergic receptor agonist, isoproterenol, elicited cumulative dosedependent relaxation of the precontracted ASM segments (Figure 7). Relative to control serum-treated ASM (Figure 7, open circles), the maximal relaxation responses $\left(\mathrm{R}_{\max }\right)$ and sensitivities $\left(\mathrm{pD}_{50}\right.$; i.e., $\left.-\log \mathrm{ED}_{50}\right)$ to isoproterenol were significantly attenuated in the corresponding atopic asthmatic serum-sensitized tissues (Figure 7 , filled circles). Accordingly, the mean $\mathrm{R}_{\max }$ values for isoproterenol amounted to $53.7 \pm 5.2 \%$ in the atopic sensitized ASM, compared with $71.5 \pm 7.9 \%$ in the control serum-treated TSM $(P<0.05)$, with corresponding $\mathrm{pD}_{50}$ values averaging $6.18 \pm 0.12$ and $6.51 \pm 0.08-\log \mathrm{M}$, respectively $(P<0.05)$. The attenuated isoproterenolinduced relaxation responses, however, were ablated in atopic asthmatic serum-sensitized ASM that were pretreated with IFN- $\gamma$ (Figure 7, filled squares). Contrasting the observations made in atopic asthmatic serum-sensitized ASM, pretreatment of control serum-exposed tissues with IFN- $\gamma$ did not affect the tissues' subsequent contractility to ACh or relaxation responsiveness to isoproterenol (data not shown).

Modulatory actions of TH2 cytokines on ASM responsiveness in naive ASM. In view of the findings just described, together with previous evidence implicating a role for TH 2 cytokines in the pathobiology of asthma, we next examined whether the proasthmatic sensitizing effects of atopic asthmatic serum on ASM responsiveness could be simulated by treating naive ASM with exogenously administered TH2-type cytokines. Accordingly, constrictor and relaxant dose-response relationships to ACh and isoproterenol, respectively, were separately compared in ASM exposed for 24 hours to vehicle alone (control) or to either IL-4, IL-5, or GM-CSF (see Methods). As shown in Figure 8, relative to their respective controls (Figure 8, open circles), the $\mathrm{T}_{\max }$ responses to ACh were significantly $(P<0.05)$ enhanced in tissues treated with a maximally effective concentration $(5 \mathrm{ng} / \mathrm{ml}$ ) of IL-5 (Figure 8, filled circles), wherein the mean $\pm \mathrm{SE} \mathrm{T}_{\max }$ responses amounted to $118.1 \pm 12.0$ vs. $92.7 \pm 3.6 \mathrm{~g} / \mathrm{g}$ ASM wt obtained in the control tissues. Similarly, the $\mathrm{T}_{\max }$ responses to ACh were also significantly $(P<0.05)$ enhanced in tissues treated with a maximum effective concentration $(2 \mathrm{ng} / \mathrm{ml})$ of GM-CSF (Figure 8, filled squares), wherein the mean \pm SE $\mathrm{T}_{\max }$ responses amounted to $112.4 \pm 8.4 \mathrm{~g} / \mathrm{g}$ ASM wt. Contrasting the effects of these $\mathrm{TH} 2$ cytokines, administration of IL-4 had no appreciable effect on the tissues' constrictor responsiveness to ACh (data not shown).

In concert with these observations, during similar initial sustained levels of ACh-induced contractions (i.e., $\left.\sim 45 \% \mathrm{~T}_{\max }\right)$, as shown in Figure 9, the subsequent relaxation responses to cumulative administration of isoproterenol were markedly reduced in IL-5-treated (Figure 9, filled circles) vs. control (Figure 9, open circles) tissues, wherein the $\mathrm{R}_{\max }$ responses amounted to $46.8 \pm 4.1 \mathrm{vs}$. $66.0 \pm 4.5 \%$, respectively $(P<0.01)$. Similarly, the corresponding $\mathrm{pD}_{50}$ values averaged $5.93 \pm 0.09$ vs. $6.67 \pm 0.11$ $-\log \mathrm{M}$ in the IL-5-treated vs. control tissues, respectively $(P<0.05)$. Qualitatively similar results were also obtained in tissues that were treated with GM-CSF (Figure 9, filled squares), although, quantitatively, the attenuating effect of GM-CSF on ASM relaxation was less pronounced, wherein the $\mathrm{R}_{\max }$ and $\mathrm{pD}_{50}$ values amounted to 


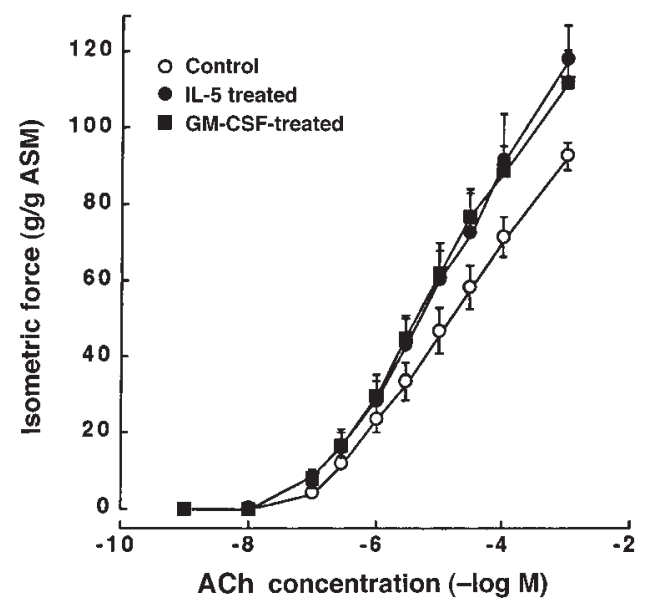

Figure 8

Comparison of airway constrictor responses to ACh in isolated paired ASM segments in the absence (open circles) and presence of 24-h exposure to maximum effective concentrations of IL-5 (filled circles) and GM-CSF (filled squares). Relative to controls, both the $\mathrm{T}_{\max }$ and $\mathrm{ED}_{50}$ values to $\mathrm{ACh}$ were significantly enhanced in the presence of IL-5 and GM-CSF. Data represent mean $\pm S E$ values from six paired experiments.

$56.93 \pm 3.67 \%$ and $5.85 \pm 0.10-\log \mathrm{M}$, respectively $(P<$ $0.05)$. In contrast, IL-4 had no effect on the tissues' relaxation responses to isoproterenol (data not shown).

Taken together, these observations demonstrate that HASM expresses both TH1- and TH2-type cytokines and their receptors and that activation of these receptors serves to downregulate and upregulate proasthmatic perturbations in ASM responsiveness, respectively.

\section{Discussion}

Bronchial asthma is characterized by exaggerated agonist-induced bronchoconstriction, attenuated $\beta$-adrenoceptor-mediated airway relaxation and airway inflammation, the latter typically involving infiltration of the airways with mast cells, lymphocytes, and eosinophils (1-4). Although the mechanistic interplay between inflammation and the associated changes in airway responsiveness remains to be identified, a growing number of studies $(5,19-21)$ have demonstrated that the changes in airway responsiveness in asthmatic individuals are associated with elevated serum and BAL fluid levels of the TH2 phenotype of cytokine release, principally including IL-4 and IL-5. In addition, mononuclear cells isolated from serum or BAL fluid samples from atopic asthmatic patients have been found to display an enhanced TH2-type cytokine response when activated by ligand. Moreover, emerging data derived from genetic analyses of family members with allergic asthma have demonstrated a significant direct correlation between altered airway responsiveness and IL-4 and IL- 5 cytokine levels in serum or BAL fluid samples $(5,19,28)$.

The roles of the TH2 cytokines in allergic asthma have been reasonably well characterized. IL-4 was found to direct immunoglobulin isotype switching to IgE synthesis, and IL-5 was found to be primarily responsible for mast cell and eosinophil differentiation, recruitment, and activation (10-12). These cytokines thus appear to serve important functions in initiating and/or propagating the proinflammatory airway response in asthma as it relates to allergen sensitization, IgE production, and eosinophil action. In contrast to the TH 2 cytokine actions, the TH1 cytokines, as most notably reflected by IFN- $\gamma$, have been generally associated with amelioration of airway constrictor hyperresponsiveness and a reduction in TH2 cytokine expression and action in patients with asthma (13-18). IFN- $\gamma$ has been found to inhibit IL-4-driven immunoglobulin isotype switching to $\operatorname{IgE}$ synthesis (15-17), inhibit the proliferation of TH2 cells $(29,30)$, and promote the differentiation of precursor TH0 cells into those expressing a TH1 phenotype (30). This evidence, together with the findings that expression of IFN$\gamma$ protein and BAL fluid levels of IFN- $\gamma$ positive cells are generally reduced in the lungs of asthmatic subjects (5, 19-21), supports the notion that an imbalance in the net expression and action of TH2 vs. TH1 cytokines, characterized by an upregulated $\mathrm{TH} 2$ cytokine response and downregulated TH1 response, fundamentally underlies the proinflammatory diathesis in atopic asthma.

In light of the findings described above, the present study investigated the potential roles of TH1- and TH2type cytokines in regulating airway responsiveness by examining whether the ASM itself expresses and responds to these cytokine subtypes. The rationale for addressing this issue was based, in part, on our recent evidence demonstrating that the ASM itself can be induced to express specific proinflammatory cytokines (notably, IL-1 $\beta$ ) in the atopic asthmatic-sensitized state and responds to IL- $1 \beta$ in an autocrine manner that establishes proasthmatic phenotypic changes in the ASM tissues' constrictor and relaxant responsiveness $(25,26)$. Our results herein provide evidence demonstrating that: (a) human ASM tissue and cultured ASM cells express mRNAs and proteins for certain TH1- and TH2-type cytokines and their receptors; $(b)$ the expression of these cytokines and their receptors is upregulated during passive sensitization of the ASM with human atopic asthmatic serum; and (c) this upregulated cytokine expression is characterized by an initial relatively enhanced expression of the TH2-type cytokines, IL-5 and GM-CSF, followed hours later by an enhanced expression of the TH1type cytokines, IL-2, IL-12, and IFN- $\gamma$. Moreover, our extended findings demonstrate that TH1- and TH2-type cytokines exert opposing direct effects on ASM constrictor and relaxant responsiveness, whereby: (a) administration of the TH1 cytokines, IL-2 and IFN- $\gamma$, acts to attenuate the heightened ASM constrictor and reduced ASM relaxant responsiveness, respectively, in atopic asthmatic serum-sensitized tissues; and $(b)$ administration of the TH 2 cytokines, IL-5 and GM-CSF, to naive ASM tissues induces proasthmatic changes in the tissues' constrictor and relaxant responsiveness.

To our knowledge, this study is the first to demonstrate that smooth muscle cells have the capacity to express both TH1- and TH2-type cytokines and their respective receptors and to physiologically respond to these molecules. Our results concur with those in recent reports that have also demonstrated the elaboration of certain TH1and TH2-type cytokines by other resident tissue (i.e., non-bone marrow derived) cells including epithelial cells 
(31), keratinocytes (32), and other cell types $(33,34)$. These findings, together with our present observations, support the notions that expression of the TH1- and $\mathrm{TH} 2$-type cytokine profiles is not restricted to $\mathrm{CD}^{+} \mathrm{TH}$ cells and that the release of these cytokines by airway smooth muscle and other resident tissue cells may serve to regulate local tissue physiological and immune responses in a manner somewhat analogous to the known behavior of TH cells. The latter, when activated, secrete cytokines that they use for autocrine effects (e.g., proliferation) and to influence the development and function of immediately adjacent effector cells. Indeed, recent studies have demonstrated that cytokines act very locally and do not diffuse widely $(35,36)$. Given this evidence, the consideration is raised that our observed perturbations in ASM responsiveness in the atopic asthmatic sensitized state reflect, at least in part, the net effect of the autocrine actions of specific TH1- and TH2-type cytokines released by the ASM itself. To the extent that our findings pertain to in vitro experimental conditions, however, the potential role of such an ASM autocrine mechanism in inducing autologous changes in ASM responsiveness in vivo remains to be elucidated. In this context, identification of the potential in vivo role of the latter autocrine mechanism in eliciting altered ASM responsiveness would require partitioning of its contribution from those possibly mediated by airway infiltrating TH cells and other proinflammatory and airway resident cell types (e.g., epithelial cells).

Our results showing that ASM expression of the mRNAs and proteins for both TH1- and TH2-type cytokines and their receptors is upregulated in the atopic asthmatic serum-sensitized state raise certain noteworthy considerations. Among these, as a first approximation, the results appear to differ from the prevailing concepts, largely derived from studies examining murine $\mathrm{TH}$ cell differentiation, that mature and fully differentiated TH cells are "polarized" in their expression of either a TH1- or TH2-type phenotype and that the commitment of a given $\mathrm{TH}$ cell alone to one or the other phenotype is irreversible (37). On the other hand, less differentiated $\mathrm{TH}$ precursor cells are known to progress through an intermediate TH0 stage, which is characterized by the stimulated production of both TH1- and TH2-type cytokines including IL-2, IL-4, and IFN- $\gamma$ (38). In view of the latter, it could be argued that our observed upregulated expression of both TH1- and TH2-type cytokines by atopic asthmatic serum-sensitized ASM phenotypically resembles the behavior of stimulated THO cells. Additionally, in contrast to mice, it should be noted that the most common clonal phenotype of TH cells isolated from healthy humans is given by the production of both TH1- and TH2-type cytokines, including IL-4, IL-2, and IFN- $\gamma$ (39). Moreover, it has been identified that these cytokines are often released even by allergen-specific activated $\mathrm{T}$ cell clones $(40,41)$ and that other human $\mathrm{TH}$ cell clones can elaborate IL-5 and IFN- $\gamma(42)$. This evidence, together with more recent findings demonstrating that serum or BAL fluid levels of IFN- $\gamma$ and IFN- $\gamma$-producing cells may be increased in patients having moderate to severe asthma $(43,44)$, suggests that the atopic asthmatic state is not necessarily manifested by selective expression of the TH2 phenotype. Our present observations in atopic asthmatic serum-sensitized ASM concur with the latter notion, and, as noted later here, the results further suggest a potential mechanism by which TH1- and TH2-type cytokine expression by sensitized ASM may contribute to its physiological expression of the atopic asthmatic phenotype.

Consideration of this potential mechanism relates to our observed temporal patterns of increased expression of the TH1- and TH2-type cytokines and their receptors during the course of passive sensitization of ASM with atopic asthmatic serum. The results demonstrate that an initial transient (i.e., at 3 and 6 hours) increased expression by sensitized ASM of the TH2-type cytokines, IL-5 and GM-CSF (Figure 1), and their receptors (Figure 4b) is followed hours later (i.e., at 6 and 24 hours) by an increased expression of the TH-1 type cytokines, IL-2, IL12 , and IFN- $\gamma$ (Figure 2) and their receptors (Figure 4a). These findings, when considered in light of our extended pharmacodynamic observations demonstrating that: (a) administration of TH2-type cytokines elicits proasthmatic phenotypic changes in ASM responsiveness (Figures 8 and 9); and (b) the latter phenotype in ASM responsiveness is inhibited by administrating the TH1type cytokines, IL-2 and IFN- $\gamma$ (Figures 6 and 7), support the notion of an autologously controlled temporal variation in the contributions of mechanisms regulating the proasthmatic state in sensitized ASM. Accordingly, after its initial autologous induction of the proasthmatic phenotypic responsiveness in association with TH2-type cytokine release, the sensitized ASM initiates the expression of TH1-type cytokines that act to subsequently downregulate (or attenuate) the manifestation of the proasthmatic state of altered ASM responsiveness. While our results herein provide some evidence in support of this hypothesis, and extended studies are clearly needed to systematically address this issue, it is relevant that the

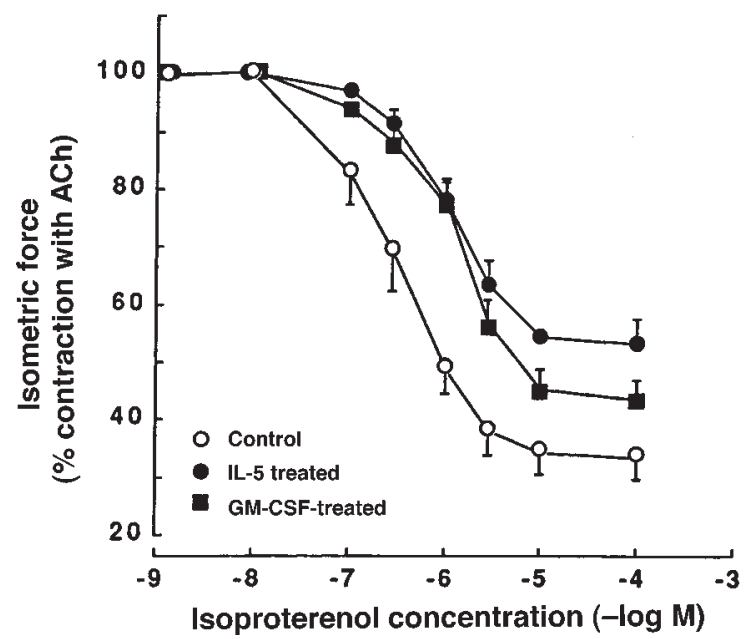

Figure 9

Comparison of airway relaxation responses to isoproterenol in paired ASM segments in the absence (open symbols) and presence of 24-h exposure to maximum effective concentrations of IL-5 (filled circles) and GMCSF (filled squares). Relative to controls, both the $\mathrm{R}_{\max }$ and $\mathrm{pD}_{50}$ values to isoproterenol were significantly attenuated in the presence of IL-5 and GM-CSF. Data represent mean \pm SE values from six paired experiments 
phenomenon of interconversion between TH 2 and TH1 responses through cross-regulation has been demonstrated in TH cells under various experimental conditions (45-47). The potential mechanism(s) underlying this switching in TH responsiveness remains to be identified; however, evidence demonstrating that such switching indeed occurs suggests that TH1 and TH2 responses may coexist before one or the other phenotype dominates in its expression and action.

Using the same experimental model described herein, we previously demonstrated that the proasthmatic perturbations in ASM responsiveness obtained in rabbit ASM passively sensitized with human atopic asthmatic serum are fundamentally initiated by IgE-induced activation of its low-affinity receptor, FcERII (or CD23), in ASM (48). Moreover, we found that activation of FceRII is associated with the autologously induced release and autocrine action of the proinflammatory cytokine, IL$1 \beta$, in the sensitized $\operatorname{ASM}(25,26)$. The latter cytokine apparently produces the observed changes in ASM responsiveness secondary to the induced upregulated expression and action of Gi protein, specifically $\mathrm{Gi}_{2}$ and $\mathrm{Gi \alpha}_{3}(26)$, that inhibit intracellular cAMP accumulation (26). Given this sequence of events, the present results raise the notion that our comparably observed IL-5- and, to a lesser extent, GM-CSF-induced changes in ASM responsiveness may be mediated by a similar mechanism involving the autocrine release and action of IL-1 $\beta$. Clearly, the existence of such an intrinsic autocrine network involving TH2-type cytokines and IL- $1 \beta$ release and action in atopic sensitized ASM needs to be investigated, particularly given the compelling recent evidence demonstrating that activated $\mathrm{TH} 2$ cells can synthesize their own IL-1 $\beta(45,49)$.

In conclusion, the present study demonstrated the presence and autologously upregulated expression of TH1and TH2-type cytokines and their respective receptors in atopic asthmatic sensitized ASM. Furthermore, the results demonstrated that the latter phenomenon is associated with the induction of altered airway responsiveness in the atopic asthmatic sensitized state. These findings, together with additional evidence depicting the temporal patterns of change in the expression of these cytokines, and their opposing direct actions on airway responsiveness, identify a potentially important role for the resident ASM in autologously regulating its own state of altered responsiveness in the atopic asthmatic condition.

\section{Acknowledgments}

The authors thank Judith Grunstein, Cecilia Kim, Sing Chang, and Saidee Ling for expert technical assistance, and Margaret Brown for assisting with typing the manuscript. H. Hakonarson is a Children's Health Research Center Investigator and Parker B. Francis Fellow in Pulmonary Research. This work was supported in part by grants from the National Heart, Lung and Blood Institute (HL-31467 and HL-58245), and by an Institutional Developmental Fund Award from the Joseph Stokes, Jr., Research Institute of the Children's Hospital of Philadelphia.

1. Bai, T.R. 1990. Abnormalities in airway smooth muscle in fatal asthma. Am. Rev. Respir. Dis. 141:552-557.

2. Goldie, R.G., Spina, D., Henry, P.J., Lulich, K.M. and Paterson, J.W. 1986. In vitro responsiveness of human asthmatic bronchus to carbachol, histamine, $\beta$-adrenoceptor agonists and theophylline. Br. J. Clin. Pharmacol. 22:669-676.
3. Bousquet, J., et al. 1990. Eosinophilic inflammation in asthma. N. Engl. J. Med. 323:1033-1039.

4. Djukanovic, R., et al. 1990. Mucosal inflammation in asthma. Am. Rev. Respir. Dis. 142:434-457.

5. Robinson, D.S., et al. 1992. Predominant Th2-like bronchoalveolar Tlymphocyte population in atopic asthma. N. Engl. J. Med. 326:298-304.

6. Walker, C., et al. 1992. Allergic and nonallergic asthmatics have distinct patterns of T-cell activation and cytokine production in peripheral blood and bronchoalveolar lavage. Am. Rev. Respir. Dis. 146:109-115.

7. Ackerman, V., et al. 1994. Detection of cytokines and their cell sources in bronchial biopsy specimens from asthmatic patients: relationship to atopic status, symptoms, and level of airway hyperresponsiveness. Chest. 105:687-696.

8. Corrigan, C.J., et al. 1995. Peripheral blood CD4 but not CD8 T-lymphocytes in patients with exacerbation of asthma transcribe and translate messenger RNA encoding cytokines which prolong eosinophil survival in the contest of a Th2-type pattern: effect of glucocorticoid therapy. Am. J. Respir. Cell Mol. Biol. 12:567-578.

9. Humbert, M.S., et al. 1996. IL-4 and IL-5 mRNA and protein in bronchial biopsies from patients with atopic and non-atopic asthma: evidence against "intrinsic" asthma being a distinct immunopathologic entity. Am. J. Respir. Crit. Care Med. 154:1497-1504.

10. Koning, H., Neijens, H.J., Baert, M.R.M., Oranje, A.P., and Savelkoul, H.F.J. 1997. T cell subsets and cytokines in allergic and non-allergic children. II. Analysis of IL-5 and IL-10 mRNA expression and protein production. Cytokine. 9:427-436.

11. Gascan, H., et al. 1994. Regulation of human IgE synthesis. Clin. Exp. Allergy. 21:162-166.

12. Romagnani, S. 1995. Biology of human TH1 and TH2 cells. J. Clin. Immunol. 15:121-129.

13. Lack, G., et al. 1994. Nebulized but not parenteral IFN-g decreases IgE production and normalizes airways function in a murine model of allergen sensitization. J. Immunol. 152:2546-2554.

14. Lack, G., and Gelfand, E.W. 1996. The role of nebulized IFN- $\gamma$ in the modulation of allergic responses. In New horizons in allergy immunotherapy. A.H. Sehon et al., editors. Plenum Press. New York, NY. 17-23.

15. Snapper, C.M., and Paul, W.E. 1987. Interferon- $\gamma$ and B cells stimulatory factor- 1 reciprocally regulate $\mathrm{Ig}$ isotype production. Science. 236:944-947.

16. Coffman, R.L., and Carty, J. 1986. A T cell activity that enhances polyclonal IgE production and its inhibition by interferon- $\gamma$. J. Immunol. 136:949-954.

17. Pene, J., et al. 1988. IgE production by normal human lymphocytes is induced by interleukin 4 and suppressed by interferons, and prostaglandin $\mathrm{E}_{2}$. Proc. Natl. Acad. Sci. USA. 85:6880-6884.

18. Hessel, E.M. 1987. Development of airway hyperresponsiveness is dependent on interferon-gamma and independent of eosinophil infiltration. Am J. Respir. Cell Mol. Biol. 16:325-334.

19. Umetsu, D.T., and de Kruyff, R.E. 1997. Th1 and Th2 CD4+ cells in the pathogenesis of allergic diseases. Proc. Soc. Exp. Biol. Med. 215:1-20.

20. Hamid, Q., et al. 1991. Expression of mRNA for interleukin-5 in mucosal bronchial biopsies from asthma. J. Clin. Invest. 87:1541-1546.

21. Ying, S., Durham, S.R., Corrigan, C.J., Hamid, Q., and Kay, A.B. 1995. Phenotype of cells expressing mRNA for Th2-type (interleukins 4 and interleukin 5) and Th1-type (interleukin 2 and interferon- $\gamma$ ) cytokines in bronchoalveolar lavage and bronchial biopsies from atopic asthmatic and normal control subjects. Am. J. Respir. Cell Mol. Biol. 12:477-487.

22. Robinson, D., et al. 1993. Prednisolone treatment in asthma is associated with modulation of bronchoalveolar lavage cell interleukin-4, interleukin-5, and interferon-gamma cytokine gene expression. Am. Rev. Respir. Dis. 148:401-406.

23. Bendley, A.M., et al. 1996. Prednisolone treatment in asthma. Reduction in the numbers of eosinophils, T cells, tryptase-only positive mast cells, and modulation of IL-4, IL-5, and interferon-gamma cytokine gene expression within the bronchial mucosa. Am. J. Respir. Crit. Care Med. 153:551-556.

24. Leung, D.Y., et al. 1995. Dysregulation of interleukin 4, interleukin 5, and interferon gamma gene expression in steroid-resistant asthma. J. Exp. Med. 181:33-40.

25. Hakonarson, H., Herrick, D.J., Gonzalez-Serrano, P., and Grunstein, M.M. 1997. Autocrine role of interleukin $1 \beta$ in altered responsiveness of atopic asthmatic sensitized airway smooth muscle. J. Clin. Invest. 99:117-124.

26. Hakonarson, H., Herrick, D.J., Gonzalez-Serrano, P., and Grunstein, M.M. 1996. Mechanism of cytokine-induced modulation of $\beta$-adrenoceptor responsiveness in airway smooth muscle. J. Clin. Invest. 97:2593-2600.

27. Hakonarson, H., Herrick, D.J., and Grunstein, M.M. 1995. Mechanism of impaired $\beta$-adrenoceptor responsiveness in atopic sensitized airway smooth muscle. Am. J. Physiol. 269:L645-L652.

28. Zangrilli, J.G., et al. VCAM-1 levels after segmental antigen challenge correlate with eosinophil influx, IL-4 and IL-5 production, and the late phase response. Am. J. Respir. Crit. Care Med. 151:1346-1353. 
29. Bradley, L.M., Yoshimoto, K., and Swain, S.L. 1995. The cytokines IL-4, IFN- $\gamma$, and IL-12 regulate the development of subsets of memory effector/helper T cells in vitro. J. Immunol. 155:1713-1724.

30. Romagnani, S. 1994. Human Th1 and Th2 subsets: "Eppur si muove!" Eur. Cytokine Netw. 5:7-12.

31. Stadnyk, A.W. Cytokine production by epithelial cells. FASEB J. 8:1041-1047.

32. Luger, T.A., et al. 1990. Cytokines and the skin. Curr. Probl. Dermatol. 19:35-49.

33. Jordana, M., Sarnstrand, B., Sime, P.J., and Ramis, I. 1994. Immuneinflammatory functions of fibroblasts. Eur. Respir. J. 7:2212-2222.

34. Barker, J.N.W.N., Mitra, R.S., Griffiths, C.E.M., Dixit, V.M., and Nickoloff, B.J. 1991. Keratinocytes as initiators of inflammation. Lancet. 337:211-214.

35. Monks, C.R., Kupfer, H., Tamir, I., Barlow, A., and Kupfer, A. 1997. Selective modulation of protein kinase $\mathrm{C}$-theta during $\mathrm{T}$-cell activation. Nature. 385:83-86.

36. Bochner, B.S., Undem, B.J., and Lichtenstein, L.M. 1994. Immunological aspects of allergic asthma. Annu. Rev. Immunol. 12:295-335.

37. Reiner, S.L., and Locksley, R.M. 1995. The regulation of immunity to Leishmania major. Annu. Rev. Immunol. 13:151-177.

38. Sad, S. and Mosmann, T.R. 1994. Single IL-2-secreting precursor CD4 T cell can develop into either Th1 or Th2 cytokine secretion phenotype. J. Immunol. 153:3514-3522.

39. Nakamura, T., et al. 1997. Roles of IL-4 and IFN- $\gamma$ in stabilizing the T helper cell type 1 and 2 phenotype. J. Immunol. 158:2648-2653.

40. Nakamura, T., Kamogawa, Y., Bottomly, K., and Flavell, R.A. 1997. Polarization of IL-4 and IFN-g producing CD 4 T cells following activation of naive CD4 T cells. J. Immunol. 158:1085-1094.

41. Holtzman, M.J., Sampath, D., Castro, M., Look, D.C., and Jayaraman, S. 1996. The one-two of T helper cells: does interferon- $\gamma$ knock out the Th2 hypothesis for asthma? Am. J. Respir. Cell Mol. Biol. 14:316-318.

42. Kim, J., Woods, A., Becker-Dunn, E., and Bottomly, K. 1985. Distinct functional phenotypes of cloned Ia-restricted helper T cells. J. Exp. Med. 162:188-201.

43. Corrigan, C.J., and Kay, A.B. 1990. CD4 T-lymphocyte activation in acute severe asthma. Relationship to disease severity and atopic status. Am. Rev. Respir. Dis. 141:970-977.

44. Cembrzynska-Nowak, M., Szklarz, E., Inglot, A.D., and TeodorczykInjeyan, J.A. 1993. Elevated release of tumor necrosis factor-alpha and interferon-gamma by bronchoalveolar leukocytes from patients with bronchial asthma. Am. Rev. Respir. Dis. 147:291-295.

45. Morel, P.A., and Oriss, T.B. 1998. Crossregulation between th1 and th2 cells. Crit. Rev. Immunol. 18:275-303.

46. Mocci, S., and Coffman, R.L. 1995. Induction of a Th2 population from a polarized Leishmania-specific population by in vitro culture with IL-4. J. Immunol. 154:3779-3787.

47. Nabors, G.S., Afonso, L.C.C., Farrell, J.P., and Scott, P. 1995. Switch from a type 2 to a type $1 \mathrm{~T}$ helper cell response and cure of established Leishmania major infection in mice is induced by combined therapy with interleukin 12 and Pentostam. Proc. Natl. Acad. Sci. USA. 92:142-146.

48. Hakonarson, H., and Grunstein, M.M. 1998. Autologously up-regulated $\mathrm{Fc}$ receptor expression and action in airway smooth muscle mediates its altered responsiveness in the atopic asthmatic sensitized state. Proc. Natl. Acad. Sci. USA. 95:5257-5262.

49. Kurt-Jones, E.A., Hamberg, S., Ohara, J., Paul, W.E., and Abbas, K. 1987. Heterogeneity of helper inducer T lymphocytes. I. Lymphokine production and lymphokine responsiveness. J. Exp. Med. 166:1774-1785.

50. Chomczynski, P., and Sacchi, N. 1987. Single-step method of RNA isolation by acid guanidinium thiocyanate-phenol. choloform extraction. Anal. Biochem. 162:156-159. 